August 1986

\title{
Synthetic Heroin-Induced Parkinsonism
}

\author{
B.K. Gupta, MD \\ University of Rochester School of Medicine
}

Follow this and additional works at: https://jdc.jefferson.edu/jeffjpsychiatry

Part of the Psychiatry Commons

Let us know how access to this document benefits you

\section{Recommended Citation}

Gupta, MD, B.K. (1986) "Synthetic Heroin-Induced Parkinsonism," Jefferson Journal of Psychiatry. Vol. 4 : Iss. 2 , Article 11.

DOI: https://doi.org/10.29046/JJP.004.2.006

Available at: https://jdc.jefferson.edu/jeffjpsychiatry/vol4/iss2/11

This Article is brought to you for free and open access by the Jefferson Digital Commons. The Jefferson Digital Commons is a service of Thomas Jefferson University's Center for Teaching and Learning (CTL). The Commons is a showcase for Jefferson books and journals, peer-reviewed scholarly publications, unique historical collections from the University archives, and teaching tools. The Jefferson Digital Commons allows researchers and interested readers anywhere in the world to learn about and keep up to date with Jefferson scholarship. This article has been accepted for inclusion in Jefferson Journal of Psychiatry by an authorized administrator of the Jefferson Digital Commons. For more information, please contact: JeffersonDigitalCommons@jefferson.edu. 


\title{
Synthetic Heroin-Induced Parkinsonism
}

\author{
B.K. Gupta, M.D.
}

Parkinson's disease is a slowly progressive, neurodegenerative disorder affecting one in 1,000 of the general population; its incidence increases with age, but the cause remains unknown. The disease is characterized pathologically by a loss of neurons from the pigmented substantia nigra pars compacta, and a triad of physical symptoms of rigidity, tremor, and bradykinesia or akinesia. Thus the clinical condition of Parkinson's disease is a rather complex disorder with a variety of physical symptoms due to neuronal damage in a number of brain regions. Additional brain regions also affected in clinical Parkinson's disease include the ventral tegmental area, locus coeruleus, serotonergic dorsal raphe system, and the dorsal motor nucleus of the vagus (1). Furthermore, it has been suggested that damage to these various regions of the brain leads to a variety of motor and mental disorders (depression and dementia) that are specific to the damage in each of these neuronal systems (2). Loss of norepinephrine may lead to depression; the incidence of depression varies between 20 to 90 percent in Parkinson's disease, and many of these patients show favorable responses to tricyclic antidepressants.

Recently, several individuals developed a Parkinson-like disorder following intravenous administration of MPTP (1-methyl-4-phenyl-1,2,3,6-tetrahydropyridine). MPTP is created as a byproduct in the synthesis of a synthetic heroin 1-methyl-4-phenyl-4-propionoxypiperidine (MPPP). Admixed with varying amounts of MPPP, MPTP was illicitly sold as a new type of heroin (3) in a limited region of northern California. Many users developed a Parkinson-like disorder with bradykinesia, rigidity, tremor, flexed posture, loss of postural reflexes, and drooling following intravenous administration of MPTP (3-5). Results of MPTP use in humans demonstrated that this compound can closely reproduce the symptomatology of idiopathic Parkinson's disease, and may provide a new tool for investigating basic neurobiological and clinical aspects of Parkinson's disease, probably leading to better therapeutic approaches than what has been available so far.

\section{MPTP AND PARKINSON'S DISEASE}

A severe loss of pigmented nerve cells in the substantia nigra pars compacta and low levels of homovanillic acid in the cerebrospinal fluid have been reported

Dr. Gupta wrote this paper while a fourth-year resident at the University of Rochester School of Medicine, Rochester, New York. 
in patients with MPTP-induced Parkinsonism (4). The clinical signs and symptoms of Parkinsonism in these patients could be ameliorated by administration of L-dopa $(3,4)$; some patients experienced typical treatment-related complications of long-term L-dopa therapy such as deterioration, peak-dose dyskinesia, and "on-off" phenomena (5).

Furthermore, intravenous administration of MPTP has been reported to produce Parkinson-like symptoms in non-human primates (6-8), including bradykinesia, postural tremor, and muscular rigidity; L-dopa therapy ameliorates these problems (6). MPTP treatment resulted in decreased release of dopamine in the striatum, and dopamine accumulation in swollen axons in the nigrostriatal pathway just rostral to the substantia nigra $(6,9,10)$, followed by extensive loss of nerve cells in the pars compacta of the substantia nigra (11), and a marked reduction in the dopamine contents of the striatum. MPTP has been also shown to produce degeneration of the nigrostriatal dopaminergic system in mice $(12,13)$, as well as other monoaminergic systems $(13,14)$.

In humans, dopamine levels in the striatum decrease with age (15), but the decrease is much sharper in humans with Parkinson's disease (16). McGeer and colleagues (17) showed that substantia nigra neurons diminish in number with age, and may demonstrate qualitative differences in appearance as well, such as shriveling. These studies suggest that dopamine neurons undergo age-related changes that lead to diminished levels and synthesis of dopamine in nerve terminals, accompanied by cell loss in the substantia nigra. More recently, it has been shown that MPTP given to aging mice produces more severe physical and morphological alterations (18) that are not seen in young adult mice. The physical symptoms include bradykinesia, rigidity, and an initial resting tremor of the whole body. Neuroanatomically, there is evidence of changes in the ventral tegemental area (mesolimbic dopaminergic system that sends dopamine projections to the nucleus accumbens and the olfactory tubercle, i.e., the limbic system) as well as the locus coeruleus (noradrenergic cell group that sends projections to the cerebral cortex, cerebellum, and hippocampus). All these studies suggest that MPTP-induced animal models in non-human primates and mice may provide insight into the mechanism and cause of neuronal degeneration.

\section{MPTP AND MAO INHIBITORS}

The oxidative metabolism of MPTP to its 1-methyl-4-phenyl pyridinium analog $\left(\mathrm{MPP}^{+}\right)$is a critical feature in the neurotoxic process (19). Furthermore, the monoamine oxidase (MAO) inhibitor, pargyline, and the specific MAO-B inhibitors (deprenil, AGN-1133, AGN-1135), can prevent the conversion of MPTP to $\mathrm{MPP}^{+}$, while the specific MAO-A inhibitor, clorgyline, has no such effect (20-24). These observations suggest that MAO-B is responsible for the oxidative metabolism of MPTP to its pyridinium analog. More recently, using monoclonal antibodies to MAO-A and MAO-B in non-human primates, West- 
lund, et al (25) reported MAO-A positive cell bodies in neurons of catecholamine cell groups, while MAO-B cell bodies were observed in serotonergic raphe nuclei, including raphe dorsalis and nucleus centralis superior. These findings suggest that MPTP may be taken up into serotonergic neurons, metabolized to $\mathrm{MPP}^{+}$, released, and further taken up by the nigrostriatal and the ventral tegmental area dopaminergic systems, where damage to these neurons then occurs.

\section{REFERENCES}

1. Jellinger K: Pathology of Parkinsonism, in Recent advances in Parkinson's disease. Edited by Fahn S, Marsden CD, Jenner P, et al. Raven Press, New York, pp. 33-66, 1986.

2. Agid F, Javoy-Agid F: Peptides and Parkinson's disease. TINS 8(1):30-35, 1985

3. Langston JW, Ballard P, Tetrud J, et al: Chronic Parkinsonism in humans due to a product of meperidine-analog synthesis. Science 219:979-980, 1983

4. Davis GC, Williams AC, Markey SP, et al: Chronic Parkinsonism secondary to intravenous injection of meperidine analogues. Psychiatry Res 1:249-254, 1979

5. Langston JW, Ballard P: Parkinsonism induced by MPTP: Implications for treatment and the pathogenesis of Parkinson's disease. Can J Neurol Sci 1 1:160-165, 1985

6. Burns RS, Chiueh CC, Markey SP, et al: A primate model of ParkinsonismSelective destruction of dopaminergic neurons in the pars compacta of the substantia nigra by MPTP. Proc Natl Acad Sci USA 80:4546-4550, 1983

7. Burns RS, Markey SP, Phillips JM, et al: The neurotoxicity of MPTP in the monkey and man. Can J Neurol Sci 11:166-168, 1984

8. Phillips JM, Burns RS: The MPTP-treated monkey: An animal model of Parkinson's disease. ILAR News 27(3):8-11, 1984

9. Burns RS, LeWitt PA, Ebert MH, et al: The clinical syndrome of striatal dopamine deficiency: Parkinsonism induced by MPTP. New Eng J Med 312(22):1418-1421, 1985

10. Langston JW, Langston EB, Irwin I: MPTP-induced Parkinsonism in human and non-human primates-clinical and experimental aspects. Acta Neurol Scand 70(Suppl. 100):49-54, 1985

11. Langston JW, Forno L, Rebert CR, et al: Selective nigral toxicity after systemic administration of MPTP in the squirrel monkey. Brain Res 292:390-394, 1984

12. Heikkila RE, Hess A, Duvoisin RC: Dopaminergic neurotoxicity of MPTP in mice. Science 224:1451-1453, 1984

13. Gupta M, Felten DL, Gash DM: MPTP alters central catecholamine neurons in addition to the nigrostriatal system. Brain Res Bull 13:737-742, 1984

14. Gupta M, Felten DL, Felten SY: MPTP alters monoamine levels in systems other than the nigrostriatal dopaminergic system in mice, in MPTP-A neurotoxin producing a Parkinsonian syndrome. Edited by Markey SP, Castagnoli N, Jr, Tremor AJ, Kopin IJ, New York, Academic Press; 399-402, 1985

15. Carlsson A, Winblad B: Influence of age and time interval between death and autopsy on dopamine and 3-Methoxytyramine levels in human basal ganglia. J Neurol Transm 38:271-276, 1976 
16. Hornykiewicz O: Brain neurotransmitter changes in Parkinson's disease, in Movement Disorders. Edited by Marsden CD, Fahn S. Butterworth and Co, London; 41-58, 1982

17. McGeer PL, McGeer EG, Suzuki JS: Aging and extrapyramidal function. Arch Neurol 34:33-35, 1977

18. Gupta M, Gupta BK, Thomas R, et al: Aged mice are more sensitive to MPTP treatment than young adults. Neurosci Letts. (in press)

19. Markey SP, Johannessen JN, Chiueh CC, et al: Intraneuronal generation of a pyridinium metabolite may cause drug-induced Parkinsonism. Nature 311:464-467, 1984

20. Chiba K, Trevor A, Castagnoli N, Jr: Metabolism of the neurotoxic tertiary amine, MPTP, by brain monoamine oxidase. Biochem Biophys Res Commun 120:574-578, 1984

21. Heikkila RE, Manzino L, Cabbat FS, et al: Protection against the dopaminergic neurotoxicity of MPTP by monoamine oxidase inhibitors. Nature 311:467-469, 1984

22. Heikkila RE, Hess A, Duvoisin RC: Dopaminergic neurotoxicity of MPTP in the mouse: Relationships between monoamine oxidase, MPTP metabolism and neurotoxicity. Life Sci 36:231-236, 1985

23. Heikkila RE, Duvoisin RC, Fiberg JPM, et al: Prevention of MPTP-induced neurotoxicity by AGN-1133 and AGN-1135, selective inhibitors of monoamine oxidase. $B$ Eur J Pharmacol 116:313-317, 1985

24. Langston JW, Irwin I, Langston EB, et al: Pargyline prevents MPTP-induced Parkinsonism in primates. Science 225:1480-1482, 1984

25. Westlund KN, Denney RM, Kochersperger LM, et al: Distinct monoamine oxidase A and B population in primate brain. Science 230:181-183, 1985 